NOTAS DE LEITURA 


\section{O ESPAÇO DO SUSPENSE: UMA LEITURA DE BREVE ESPAÇO ENTRE COR E SOMBRA, ROMANCE DE CRISTOVÃO TEZZA}

Rosse Marye Bernardi*

cada novo romance publicado por Tezza vem crescendo o reconhecimento do seu trabalho. Os elogios são unânimes e vários críticos lhe têm salientado os recursos técnicos e sua excepcional capacidade criativa. No dizer paradigmático de Wilson Martins - talvez o mais parcimonioso e exigente de nossos críticos militantes - o autor, com Breve espaço entre cor e sombra, "chega à sua maturidade de romancista, situando a criação dos personagens, os perfis psicológicos, a intriga e as peripécias no plano intelectual da grande literatura [...]".2

Tomando a deixa do crítico, podemos acrescentar que Tezza já é senhor de uma personalidade literária sui generis, reconhecível no extraordinário tra-

* Professora aposentada da UFPR.

1 TEZZA, Cristovão. Breve espaço entre cor e sombra. Rio de Janeiro: Rocco, 1998. Todas as citações seguidas do número de página entre parênteses referem-se a esta obra.

2 MARTINS, Wilson. A obra aberta de Cristovão Tezza. $O$ Globo, Rio de Janeiro, 2 maio 1998. 
balho com a linguagem e na maestria com que domina o arcabouço narrativo e as várias vozes que povoam o seu universo. E tudo isso colocado a serviço de uma visão de mundo forjada no campo da aventura, da experiência e da paixão pelas artes.

Fugindo a uma divisão convencional em capítulos, Breve espaço entre cor e sombra estabelece o seu ritmo pela intercalação de diferentes linguagens, técnica que se configura como uma espécie de leitmotiv, pois, de forma mais ou menos sistemática, desde Trapo o autor vem organizando suas narrativas a partir da duplicidade de pontos de vista, maneira multifacetada de ver e escrever o mundo.

Na primeira narrativa, o sujeito é Tato Simmone - jovem pintor cujo discurso vem marcado por uma retórica verossímil, traduzindo a sua formação, leitura e horizonte lingüístico. Todos os seus referentes têm a marca da cor e da sombra e é a pintura que pontua de forma séria ou irônica o seu relacionamento com o mundo. Sob a perspectiva do autor, esta opção enfática por uma linguagem específica, por um jargão (na terminologia bakhtiniana), com todos os seus acentos e significados, mostra a intenção temática de trabalhar no terreno das artes plásticas, levando ao conseqüente desvendamento das difíceis relações desse meio, com todas as suas mazelas.

Como muitos artistas, Tato precisa de um mestre - um espelho, um olhar, que dê à sua pintura o aval que sua própria insegurança lhe nega. A cena inicial do romance é o enterro de Anibal Marsotti, ex-mestre e amigo, cujo corpo desce à sepultura "numa manhã azulíssima de Curitiba, esse azul único daqui, cruel e mudo, filho do frio e da timidez" (p. 9). O ritual do enterro propicia a reatualização das memórias de Tato - típico filho da provinciana Curitiba. O episódio é o estopim que deflagra uma crise existencial e a necessidade de recomeço em uma vida sem história. A partir daí lançam-se os fios que vão dar substância aos vários momentos de sua narrativa. Ainda à beira do túmulo, num humor que dessacraliza o cenário algo pungente, surgem dois fantásticos personagens - a vampira e Mr. Richard Constantin, espécie de Mefistófeles redivivo, dono de um discurso que por si só justificaria um trabalho crítico. Sedutor e cínico, Constantin desfia teorias e erudição, que bem sugerem o árduo trabalho de pesquisa realizado pelo autor. Ambos os personagens agem dessacralizando o mundo da arte - transformando-o num espaço em que imperam as ações dúbias, a ambição, a inveja, o ciúme, tudo temperado com momentos de muito humor, característica inerente à visão de mundo do autor. Já no imaginário pictórico do artista eles competem entre si pela posse da sua alma: 
Um amigo morto. Em seguida, uma vampira interessada em me ver, só para sugar a última gota do meu sangue. E agora, Mr. Satã, o demônio da sedução, pronto a comprar minha alma por um bom preço. Era tudo uma questão de barganhá-la com sabedoria. Senti falta de minha mãe. O que diria desse homem? Confiável? Não confiável? [...] (p. 23)

Será o destino de Tato igual ao de Marsotti, seu sangue será sugado, exaurindo-se suas forças em outros fins que não a arte, ou sua pintura será transformada pelo discurso do marchand que lhe oferece a fama em troca de um aperfeiçoamento técnico que nada tem a ver com a sua cabeça, com a sua visão de mundo?

No entanto, como tudo no texto oscila no limbo das possibilidades, o leitor não terá certeza de nada, nem da genialidade nem da mediocridade do artista - dependente que fica da própria indecisão do seu discurso. Neste sentido, a discussão sobre o verdadeiro e o falso na arte, e o seu desdobramento entre a autenticidade e o simulacro, $o$ original e o pastiche, vem metaforizar $o$ episódio da (falsa) cabeça de Modigliani que sustenta a (pseudo) intriga policialesca do romance. Na realidade, o episódio transcende estes limites para ganhar desdobramentos muito mais sutis e perturbadores - abrindo o espaço do texto para o exercício do suspense, considerado aqui como um valor que extrapola o seu sentido convencional. A partir da própria epígrafe do romance (“- Cómo pintas? / - Con la cabeza."), citação que Tezza foi buscar em Max Aub, a imagem se duplica, permitindo-nos mergulhar na cabeça de "um pintor de mente povoada", mas incapaz de transpor as imagens mentais para a concretude das formas e cores.

Por outro lado, o que é verdadeiramente autêntico em arte? No romance, a bela escultura leva ao engano uma crítica abalizada (a italiana) e uma marchand experiente (a mãe de Tato). Ambas atribuem autenticidade à falsificação. O que, aliás, coincide - no episódio real de Livorno, em 1984 - com o aval dado a algumas peças falsas pelo crítico Giulio Carlo Argan, ${ }^{3}$ mostrandonos assim quão tênues são as fronteiras entre o falso e o verdadeiro em matéria de arte. A chancela de autenticidade, dependente apenas de uma palavra que por sua vez também poderá ser falsa, como as falsas pistas que podem levar a uma leitura apenas superficial do texto. Assim, se no nível da intriga a cabeça,

3 TEZZA, Cristovão. Vidas paralelas. Entrevista concedida a Heitor Ferraz. CULT: Revista Brasileira de Cultura, São Paulo, n. 9, p. 21, abr. 1998. 
os telefonemas e as várias invasões na casa de Tato formam a base do suspense que coloca o leitor num horizonte de constante tensão, estes mesmos ingredientes, duplicando-se, propiciam um espaço de reflexão sobre a arte, as relações humanas e sobre a própria vida. Na visão de mundo que orquestra o texto, o suspense é o pressuposto de um universo em transformação, onde, ao contrário de uma concepção clássica do mundo, nada nem ninguém pode permanecer em repouso. Segundo o autor:

O pressuposto do suspense é o fato de que as coisas podem ser diferentes, há escolhas. Quando há suspense, o mundo não está pronto. E se há um lugar privilegiado para ele demonstrar sua completa incompletude, seu inacabamento primordial, este lugar é o romance. ${ }^{4}$

Assim, vê-se que todos os ingredientes "policialescos" têm uma função outra que não a de simplesmente desvendar um mistério, fazendo o mundo voltar à sua enganosa estabilidade. Na realidade, a história não tem fim, ela mais deixa dúvidas que certezas, enredada que está nos fios de Ariadne, a surpreendente jovem que desmistifica a verossimilhança literária, possibilitando a saída do labirinto, na opção narrativa pelo inverossímil, pelas coincidências inexplicáveis. Tato, de posse da cabeça de Modigliani, contra toda a lógica, recusa-se a livrar-se dela. Em vez de jogá-la no rio Belém para exorcizar a mentira e dar paz à mãe e à italiana, opta por deixá-la no próprio quarto, sobre um banquinho, a olhá-lo no instante do verdadeiro recomeço. É esta a metáfora de sua própria libertação. O pintor, afinal, torna-se um escritor, desenhista de personagens, senhor absoluto do território da mentira em que se move a literatura. São palavras de Ariadne, mas bem podem projetar a própria escrita do romance, que vira do avesso perspectivas e clichês.

No contraponto do discurso de Tato com sua ideologia da angústia e solidão, temos a carta da italiana, igualmente verossímil e consistente em termos ideológicos. Seu longo e pungente discurso epistolar, intercalando a narrativa do pintor - um servindo ao outro (pela própria inserção) como elemento de suspense. Os dois discursos diferem tanto sintática quanto ideologicamente, enfatizando oposições que se marcam pelos sentimentos do homem e da mulher, pela geração, pela distância temporal e espacial e por diferentes siste-

4 TEZZA, Vidas paralelas..., p. 18. 
mas de valores. No entanto, estas oposições concretizadas em dois pontos de vista sobre o mundo acabam por se iluminar mutuamente, um possibilitando a melhor compreensão do outro, na clara afirmação de que uma linguagem é sempre uma resposta a outra linguagem.

Na minha opinião, nesta carta Tezza supera a si mesmo. Dominando com maestria o processo de estilização, ele cria uma indubitável e inteligente linguagem, uma visão de mundo feminina, capaz de, num momento limite, transformar em força toda a fragilidade, medos e anseios. Maravilhosa a noção que ela tem de paixão e, mais ainda, de uma coisa terrivel e inexoravelmente humana que é o esquecimento. No seu discurso confessional a italiana vai, aos poucos, deixando de lado a idéia da morte para reconstruir-se. Esta reconstrução implica superar a traição do outro e o engano que a levara a confundir o verdadeiro e o falso, na vida e na arte. Novamente temos aqui a falsa cabeça de Modigliani - coincidência demais no plano da intriga, mas uma bela metáfora se levarmos em consideração a reflexão sobre a vida e as relações amorosas.

Um dos motivos mais instigantes no discurso da italiana, repetido quase à exaustão, são os desenhos-cartas que Tato lhe enviara ao longo de um ano de correspondência. Segundo palavras da missivista, "são treze fotogramas que se movem não no espaço, mas no avesso do tempo; a fotografia que, de tanto sol, vai se apagando, até a completa ausência de memória." (p. 70)

Como ela não quer perdê-lo, ela parte na direção oposta, construindo-o na linguagem literária:

A cada dia você mais nítido, mais completo, mais tímido e mais suave - e a lembrança das tuas mãos, os dedos tão longos, é como se eles me tocassem ainda, na limpeza desinteressada do acaso. (p. 70)

A oposição é de extrema beleza, e me parece evidente que ela aponta também para uma reflexão sobre as artes e seus recursos expressivos. Além dos dois discursos ideologicamente marcados - o de Tato e o da italiana Breve espaço entre cor $e$ sombra abre ainda espaço para a inserção de outras linguagens, que se manifestam em quatro trechos intitulados como os quadros de Tato Simmone.

O primeiro deles - "Crianças" - surge logo após a verborragia teórica de Constantin e bem pode ser uma resposta pelo avesso. Porém, mais correto talvez seja atribuir-lhe a função de presentificar a obra pictórica de Tato, ao mesmo tempo em que tematiza a impossibilidade de transpor a contento uma 
linguagem artística para outra. Em vez de uma descrição ou comentário sobre os quadros, temos uma linguagem onírica, subjetiva, aparentemente desconectada do restante da obra. A mesma experiência se repete com "Immobilis sapientia" e com "Réquiem", radicalizando-se em "Estudo sobre Mondrian", que traz a repetição monótona das mesmas expressões, num exercício puramente sintático.

No plano da estrutura romanesca, tais alternâncias discursivas ganham uma funcionalidade que se traduz em tensão no nível da leitura. Como se todos os elementos do romance, nos seus vários níveis, se unissem realizando a intenção maior do autor - fazer do texto um motivo de reflexão. 